\title{
Impact of applied Vermicompost tea and Humic Acid on Nodulation Status, Vegetative growth, and yield attributes of Bean (Phaseolus vulgaris L) plants.
}

\author{
Mona, H.A. Hussein ${ }^{1}$ and Heba. S. El-Desouky ${ }^{2}$ \\ 1-Soil, Water and Environment Research Institute, Agricultural Research Center Giza, Egypt. \\ 2- Botany Department, Faculty of Agriculture, Benha University, Egypt.
}

\begin{abstract}
This work amid to investigate the beneficial effect of Rhizobium strains, vermicompost tea and humic acid and their interactions on nodulation, vegetative growth, $\mathrm{N}, \mathrm{P}, \mathrm{K}$ mineral contents and uptake and seed yield production and its components of Bean (Phaseolus vulgaris L) plants. Results showed that application of Rhizobium leguanomis vr. Phaseolus mixed two strains with vermicompost tea and humic acid increased vegetative growth measurements i.e., plant height $\mathrm{cm} /$ plant, number of branches/plants, plant dry weight $(\mathrm{g} / \mathrm{plot})$, chlorophyll a, b and carotenoids, number of nodules per plant, dry weight of root nodule mg/plant, plant dry weight g/plant, seed number/plant, number of pods/plants, number of seed per pod, seed yield per plot during 2019 and 2020 growing seasons. In the same time other different applied treatments increased these traits as compared to un treated plants but doesn't reach the highest value like the above-mentioned treatment during both seasons.
\end{abstract}

Keywords: Phaseolus plants, Nodulation, Humic, vermicompost tea, vegetative growth and yield.

\section{Introduction}

Legumes are important sources of high quality based protein especially in developing countries. Phaseolus (phaseolus vulgaris) is a climbing perennial vegetable often grown as an annual crop for dry or immature pod production. (Foyer $\boldsymbol{e t}$ al., 2016). In Egypt Phaseolus are wildly consumed as vegetable and dry seed Phaseolus as well as it has a grate economic income values as exported legume crop. Many studies have shown that Rhizobium inoculants can improve modulation nitrogen fixation vegetative growth, yield and yield components of Phaseolus plant. They also mentioned to know that sometimes Rhizobial inoculation as such dose not gave a good response of Phaseolus plants to increase both vegetative and seed yield under different agricultures conditions. (Musondu et al., 2001, Abotaleb et al., 2003, Chianu et al., 2011 and Rurangwa et al., 2018). Vermicompost tea are products derived from the accelerated biological degradation of organic wastes by earthworms and various types of microorganisms (Edwards et al., 2004). Vermicompost tea is rich in mineral elements than commercials plant growth media. These mineral elements are available in the forms that could be taken up by the most cultivated plants, crops and their forms like soluble $\mathrm{N}, \mathrm{P}, \mathrm{K}, \mathrm{Ca}$ and $\mathrm{Mg}$ as well as some plant growth promotions regulate such as auxins, gibberellins and cytokinins (Arancon et al., 2005 and Javed et al., 2017). Humic substance which inoclude1 humic acid and fulvic acid are among the most complex and biologically active organic matter compounds in the soil and are known as a stimulate in both plants and microbial activities through a number of mechanisms such as through humic extracts of Leonardite compost or often organic fertilizers. (Khalel et al., 2011, Mohana et al., 2015 and Comallas and olivares 2016). In addition, humic acid is also a naturally available substance in the soil and a bioproduct of organic matter decomposition which was successfully used in cultivation of various crops (Schaebitz et al., 2016 and Zahra 2019). The main objective of this study is to monitor nodulation and vegetative growth and yield of Bean (Phaseolus vulgaris $L$ ) with application of two Rhizobial inoculations methods and some organic treatments under greenhouse conditions.

\section{Materials and Methods}

A pot experiment was carried out under greenhouse condition of soil, water and Environment Research Institute (SWERI) Agricultural Research Center (ARC) Giza, Egypt at the two successive seasons (2019 and 2020) to study the effects of applied both vermicompost tea and humic acid on nodulation, vegetative growth, mineral uptake and yield and components of rhizobial inoculated Phaseolus plants verity exera. Soil sample was collected from Ismailia fields, physical, and chemical properties were found in Table (1), according to (Jackson 1973). 


\section{Rhizobial inoculants:}

Two different methods of inoculum were applied, the first one $\left(\mathrm{g}_{1}\right)$ is peat -based inoculum of Rhizobium Leguminosarem $v r$. phaseolus, mixed of two strains, ARC 301 and ARC 3629 (1:1v) they applied at $4 \mathrm{~g}$ inoculum to $100 \mathrm{~g}$ seed, the second method $\left(\mathrm{g}_{2}\right)$ was the same two Rhizobial strains applied as liquid inoculum at rate of $10 \mathrm{ml}$ cultural per pot two times, they were added at planting time and at 30 days after planting (DAP) at two equal doses (10 $\mathrm{ml}$ per pot).

Table 1. Physical and chemical properties of the studied soil

\begin{tabular}{|c|c|}
\hline Properties & Value \\
\hline Coarose sand $\%$ & 49.51 \\
\hline Fine sand \% & 36.72 \\
\hline Silt \% & 9.36 \\
\hline Ciay \% & 4.41 \\
\hline Textuer & Sandy \\
\hline Sp \% & 22.37 \\
\hline pH & 7.68 \\
\hline E.c ds/m & 0.63 \\
\hline O.M \% & 0.29 \\
\hline T.N \% & 0.008 \\
\hline \multicolumn{2}{|l|}{ Soluble cation $\left(\mathbf{m e q} \mathbf{L}^{-1}\right)$} \\
\hline $\mathbf{C a}^{++}$ & 1.49 \\
\hline $\mathbf{M g}^{++}$ & 1.37 \\
\hline $\mathbf{N a}^{+}$ & 1.29 \\
\hline $\mathbf{K}^{+}$ & 0.48 \\
\hline \multicolumn{2}{|l|}{ Soluble Anions $\left(\mathrm{meqL}^{-1}\right)$} \\
\hline $\mathrm{Co}^{--}$ & 0.00 \\
\hline Hсо $^{-}$ & 1.76 \\
\hline $\mathrm{Cl}^{-}$ & 0.89 \\
\hline So4-- & 1.98 \\
\hline
\end{tabular}

Vermicompost tea (VT) is the produced derived from accelera tea as a biological degradation of organic wastes by interaction between earthworms and some active microorganisms (1 Vermi: 10 water) and applied at rate of $10 \mathrm{ml}$ per pot. Some chemical properties of Vermicompost tea are found in table (2), according to (Paye et al., 1982).

Table 2. Chemical properties of vermicompost tea.

\begin{tabular}{|c|c|c|}
\hline \multicolumn{2}{|r|}{ Chemical properties } & \multirow{2}{*}{$\frac{\text { Value }}{8.12}$} \\
\hline pH & & \\
\hline E.c & ds/m & 3.10 \\
\hline N.NH4 & ppm & 9.54 \\
\hline N.No3 & ppm & 41.53 \\
\hline T.N & ppm & 980 \\
\hline T.p & ppm & 12100 \\
\hline T.k & ppm & 16300 \\
\hline $\mathbf{F e}$ & ppm & 19.60 \\
\hline $\mathbf{Z n}$ & ppm & 8.41 \\
\hline Mn & ppm & 5.01 \\
\hline $\mathbf{C u}$ & ppm & 2.11 \\
\hline
\end{tabular}

Humic acid (HA) is an organic compound applied at $5 \mathrm{ml}$ per pot. Both Vermicompost tea and Humic acid were divided into equal doses and applied at 15 and 40 DAP. Bean seeds were planted in plastic pots $30 \mathrm{~cm}$ diameter filled with $10 \mathrm{~kg}$ sterilized sandy soil using $\mathrm{Naocl}_{3} 3.0 \%$ then washed several times with distilled water. Six Bean seeds were sown in each pot, after germination seedlings were thinned out to 4 healthy plants. Pots were received both phosphorus (P) in the form of super monophosphate $15.5 \% \mathrm{p}_{2} \mathrm{O}_{5}$ $(0.25 \mathrm{~g}$ per pot) and potassium $(\mathrm{K})$ in the form of potassium sulfate $48 \% \mathrm{k}_{2} \mathrm{O}(0.12 \mathrm{~g}$ per pot $)$. Nitrogen was applied at two rates as full dose (FND) and $1 / 3$ Nitrogen from the recommended dose ( 3 and $1 \mathrm{~g}$ per pot) in the form of ammonium sulfate $20.5 \%$ Ten treatment were applied with 3 replicates as follows: 
$\mathrm{T}_{1}$ - Full Nitrogen (FND) recommended dose of nitrogen,

$\mathrm{T}_{2}-1 / 3 \mathrm{~N}_{1}, \mathrm{~T}_{3}-1 / 3 \mathrm{~N}+\mathrm{g}_{1}$,

$\mathrm{T}_{4-} \mathrm{g}+1 / 3 \mathrm{~N}+\mathrm{H} . \mathrm{C}$,

$\mathrm{T}_{5-} \mathrm{g}_{1}+1 / 3 \mathrm{~N}_{1}+\mathrm{VT}$,

$\mathrm{T}_{6-} \mathrm{g}_{1}+1 / 3 \mathrm{~N}+\mathrm{H} . \mathrm{C}+\mathrm{VT}$,

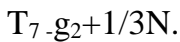

$\mathrm{T}_{8}-\mathrm{g}_{2}+1 / 3 \mathrm{~N}+\mathrm{H} . \mathrm{A}$,

$\mathrm{T}_{9}-\mathrm{g}_{2}+1 / 3 \mathrm{~N}+\mathrm{VT}$,

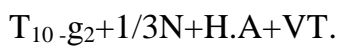

\section{Sampling and collecting data:}

plant samples were collected after 60 days after planting to determine plant height (cm per plant) number of branches, total plant dry weight, number of nodules per plant, nodule dry weight (mg per plant) plant dry weight photosynthetic pigments (chlorophyll $\mathrm{A}, \mathrm{B}$ and Carotenoids) and plant $\mathrm{N}$ (mg per plant) as well as $\mathrm{P}$ and $\mathrm{K}$ uptake as percentage (\%).

\section{Yield and yield components}

Grain yield per plant and per acre were recorded, number of pods per plants, Number of seeds per pod and Pod weight (g per plant). And seed yield per plot
Statistical analysis for collected data were compared by least significant difference (LSD) at 5\% level of probability test according to procedures out lined by (Steel et al., 1997).

\section{Results and Discussion}

Data presented in table (3) showed that plant light of Phaseolus plant $(\mathrm{cm})$ ranged from 29.78 to $43.75 \mathrm{~cm}$ per plant thought the tow tested seasons. Application of both humic acid and Vermicompost tea alone or in combination to inoculated Phaseolus plants with $\left(g_{1}\right)$ or $\left(g_{2}\right)$ gave higher values as compared to the treatments which received $\mathrm{N}$. mineral fertilizer at rate of $1 / 3 \mathrm{~N}$ from the full dose. No significant difference were found between Bean plants which received full $\mathrm{N}$. mineral fertilizer dose $\left(\mathrm{T}_{1}\right)$ and Phaseolus plants inoculated with $\mathrm{g}_{1}\left(\mathrm{~T}_{6}\right)$ or $\mathrm{g}_{2}\left(\mathrm{~T}_{10}\right)$ In combination with humic acid +Vermicompost tea $+1 / 3 \mathrm{~N}$ and their values were $42.43,40.86$ and 39.95 fer $T_{1}, T_{6}$ and $T_{10}$ respectively. For number of branches there were no significant increases are recorded among the all tested treatments and the treatments $T_{1}$, $\mathrm{T}_{6}$ and $\mathrm{T}_{10}$ record the highest value of number of branches when compared to other tested treatments.

Table 3. plant height $\left(\mathrm{cm} \mathrm{plant}^{-1}\right)$ number of branches (no plant $\left.{ }^{-1}\right)$ and total plant dry weight $(\mathrm{g}$ plot) of Bean plants as affected by application the two different inoculation methods under various fertilization treatments (at $60 \mathrm{DAP}$ ).

\begin{tabular}{|c|c|c|c|c|c|c|c|c|c|}
\hline \multirow[b]{3}{*}{$\mathbf{T}_{1} \mathbf{F N}$} & \multicolumn{3}{|c|}{ Plant heigh (cm plant $\left.{ }^{1}\right)$} & \multicolumn{3}{|c|}{ Number of branches } & \multicolumn{3}{|c|}{$\begin{array}{c}\text { Plant dry weight (g } \\
\text { plot }^{-1} \text { ) }\end{array}$} \\
\hline & $\mathbf{S}_{1}$ & $\mathbf{S}_{2}$ & $\mathbf{x}^{-}$ & $\mathbf{S}_{1}$ & $\mathbf{S}_{2}$ & $\mathbf{x}^{-}$ & $\mathbf{S}_{1}$ & $\mathbf{S}_{2}$ & $\mathbf{x}^{-}$ \\
\hline & 41.11 & 43.75 & 42.43 & 4 & 4 & 4 & 8.37 & 9.21 & 8.79 \\
\hline $\mathrm{T}_{2} \mathbf{1 / 3 N}$ & 29.78 & 30.11 & 29.95 & 3 & 3 & 3 & 5.43 & 5.62 & 5.53 \\
\hline $\mathrm{T}_{3} \mathrm{~g}_{1}+\mathbf{1 / 3 N}$ & 35.54 & 36.92 & 36.23 & 3 & 3 & 3 & 6.21 & 6.31 & 6.26 \\
\hline $\mathrm{T}_{4} \mathrm{~g}_{1}+1 / 3 \mathrm{~N}+\mathrm{HA}$ & 37.12 & 38.17 & 37.65 & 3 & 3 & 3 & 6.62 & 6.78 & 6.70 \\
\hline$T_{5} g_{1}+1 / 3 N+V T$ & 39.41 & 40.11 & 39.76 & 3 & 3 & 3 & 6.92 & 7.03 & 6.98 \\
\hline $\mathrm{T}_{6} \mathrm{~g}_{1}+1 / 3 \mathrm{~N}+\mathrm{HA}+\mathrm{VT}$ & 40.39 & 41.33 & 40.86 & 4 & 4 & 4 & 7.18 & 7.38 & 7.28 \\
\hline $\mathrm{T}_{7} \mathrm{~g}_{2}+\mathbf{1} / \mathbf{3 N}$ & 32.75 & 33.76 & 33.26 & 3 & 3 & 3 & 6.19 & 6.24 & 6.22 \\
\hline $\mathrm{T}_{8} \mathrm{~g}_{2}+1 / 3 \mathrm{~N}+\mathrm{HA}$ & 36.77 & 38.11 & 37.44 & 3 & 3 & 3 & 6.43 & 6.51 & 6.47 \\
\hline$T_{9} g_{2}+1 / 3 N+V T$ & 38.11 & 39.77 & 38.44 & 3 & 3 & 3 & 6.72 & 6.83 & 6.78 \\
\hline$T_{10} g_{2}+1 / 3 N+H A+V T$ & 39.17 & 40.73 & 39.95 & 4 & 4 & 4 & 6.93 & 7.11 & 7.02 \\
\hline $\mathbf{X}^{-}$ & 37.02 & 38.38 & 37.65 & 3.3 & 3.3 & 3.3 & 6.70 & 6.90 & 6.80 \\
\hline L.S.D & 1.53 & 2.27 & - & N.s & N.s & - & 1.38 & 1.83 & - \\
\hline
\end{tabular}

Table (3) data indicated that applied of rhizobial inoculation $\left(\mathrm{g}_{1}\right.$ or $\left.\mathrm{g}_{2}\right)+1 / 3 \mathrm{~N}$ in combination with humic acid and or Vermicompost tea gave higher values as compared to the plant received $1 / 3 \mathrm{~N}$ alone. The height values of total plant dry weight (g per plot) were recorded at the $\mathrm{T}_{1}, \mathrm{~T}_{6}$ and $\mathrm{T}_{10}$ and no significant difference were found between there treatment and there values were $8.79,7.28$ and 7.02 fer $\mathrm{T}_{1}, \mathrm{~T}_{6}$ and $\mathrm{T}_{10}$ respectively.
Results of nodule number (no per plant) and nodule dry weight (mg per plant) as well as plant dry weight (g per plant) presented at Table (4) clearly that un inoculated plants have no nodule formed at both $\left(\mathrm{T}_{1}\right.$ and $\mathrm{T}_{2}$ ) inoculated plants with specific rhizobia either inoculation methods $\mathrm{g}_{1}$ or $\mathrm{g}_{2}$ in combination with $1 / 3 \mathrm{~N}$ manual $\mathrm{N}$. Fertilizer dose developed a bigger number of nodules with higher dry weight. Application of humic acid and Vermicompost tea as 
such or in combination increased both nodule number and nodule dry weight of inoculated Bean plants and there values ranged from is to 29 for nodule number and from 27.8 to 63.72 for nodule dry weight. Application of seed inoculation method $\left(\mathrm{g}_{1}\right)$ led to record higher values for nodule number (nod. no. per plant) as well as nodule dry weight (mg nod per plant) as compared to liquid inoculation method $\left(\mathrm{g}_{2}\right)$ treatment among the all tested treatments. The higher values for nodule number and nodule dry weight were recorded at the treatments which received $\mathrm{g}_{2}+\mathrm{H} . \mathrm{c}+\mathrm{VT}+1 / 3 \mathrm{~N}\left(\mathrm{~T}_{6}\right)$ and there values were 29 and 63.72 my respectively.

Plant dry weight (g per plant) data in table (4) indicated that application the two different inoculation methods $\left(g_{1}\right.$ and $\left.g_{2}\right)$ in combination with humic acid and Vermicompost tea $+1 / 3 \mathrm{~N}$ Led gave higher values for plants dry weight and scored no significant values as compared to the treatments which received full dose of mineral N. Fertilizer and 1/3N.The higher values of plant dry weight at treatment $T_{1}, T_{6}$ and $T_{10}$ and their values were $1.61,1.44$ and $1.44 \mathrm{~g}$ plant respectively. The abovementioned data are in agreement with these obtained by ( (Srinivaon et al., 1997 Abo taleb et al., 2003, Liu et al., 2011 ,Rurangwa et al., 2018 and Malind et al., 2019) who reported that inoculated Phaseolus plants with who reported that Inoculated Phaseolus plants with specific rhizobia in presences of lower amount of minual N. Fertilizer (20 to $30 \%$ from recommend N dose) in combination with organic Fertilizer and or organic promote substance induced root hair, proliferation and improved modulation process and some properties plant height, branches and plant dry weight and they suggested that the stimulate planting effect was probably due to the production of some plant growth promoting substance such as I.A.A, GA, or enhancement some physical and chemical soil properties (pH, E.C, W.H.C....act).

The values of photosynthesis pigment in Phaseolus leaves (chlorophyll A chlorophyll B, chlorophyll total and carotenoids -mg per g), at Table (5).

Table 4. Number of nodules, dry weight of nodules and plant dry weight of Bean plants as affected by the application of two different inoculation methods under virous fertilization treatments (at 60 DAP).

\begin{tabular}{lccccccccc}
\hline & \multicolumn{3}{c}{ Number of nodules } & \multicolumn{2}{c}{ Dry weight of nodule } & \multicolumn{3}{c}{ Plant dry weight } \\
\cline { 2 - 11 } & $S_{1}$ & $S_{2}$ & $x^{-}$ & $S_{1}$ & $S_{2}$ & $x^{-}$ & $S_{1}$ & $S_{2}$ & $x^{-}$ \\
\hline$T_{1}$ FN & 0 & 0 & 0 & 0 & 0 & 0 & 1.59 & 1.63 & 1.61 \\
$T_{2} 1 / 3 N$ & 0 & 0 & 0 & 0 & 0 & 0 & 1.21 & 1.24 & 1.23 \\
$T_{3} g_{1}+1 / 3 N$ & 17 & 18 & 18 & 30.40 & 32.21 & 31.31 & 1.31 & 1.33 & 1.32 \\
$T_{4} g_{1}+1 / 3 N+H A$ & 18 & 20 & 19 & 34.73 & 37.89 & 36.31 & 1.38 & 1.39 & 1.39 \\
$T_{5} g_{1}+1 / 3 N+V T$ & 21 & 24 & 23 & 47.58 & 52.96 & 50.27 & 1.43 & 1.44 & 1.44 \\
$T_{6} g_{1}+1 / 3 N+H A+V T$ & 23 & 29 & 26 & 51.57 & 63.72 & 57.65 & 1.47 & 1.48 & 1.47 \\
$T_{7} g_{2}+1 / 3 N$ & 15 & 17 & 16 & 27.84 & 31.42 & 29.63 & 1.29 & 1.31 & 1.30 \\
$T_{8} g_{2}+1 / 3 N+H A$ & 16 & 19 & 18 & 32.51 & 35.72 & 34.12 & 1.33 & 1.35 & 1.34 \\
$T_{9} g_{2}+1 / 3 N+V T$ & 17 & 21 & 18 & 36.82 & 41.72 & 39.27 & 1.39 & 1.42 & 1.41 \\
$T_{10} g_{2}+1 / 3 N+H A+V T$ & 21 & 26 & 24 & 43.18 & 52.11 & 47.65 & 1.43 & 1.45 & 1.44 \\
\multicolumn{1}{c}{ X } & 19 & 22 & 21 & 38.08 & 43.47 & 40.78 & 1.38 & 1.40 & 1.39 \\
\hline \multicolumn{1}{c}{ L.S.D } & 2.17 & 3.62 & - & 4.73 & 5.21 & - & 0.13 & 0.18 & - \\
\hline
\end{tabular}

Data presented at Table (5) clearly showed that by application both humic acid and vermicompost tea $+1 / 3 \mathrm{~N}$ on inoculated Phaseolus plants the photosynthesis pigment (Chl. A, chl. B, chl. total and carot.) content were significantly influenced and increased and recorded higher values as compared to applied the two rates of $\mathrm{N}$. mineral fertilizer the higher values were $2.87,2.34,4.15$ and 8.67 for chl. A, chl. $\mathrm{B}$, chl. total and carot. at the treatments which received $\mathrm{g}_{1} \mathrm{HA}+\mathrm{VT}+1 / 3 \mathrm{~N}$ Phaseolus plants $\left(\mathrm{T}_{6}\right)$ followed by
$\mathrm{T}_{10}$ and $\mathrm{T}_{1}$ and the cross ponding values were 1.98 , $2.21,3.72$ and 7.82 and $1.93,2.01,3.57$ and 8.50 for $\mathrm{T}_{6}$ and $\mathrm{T}_{1}$ in the some order these data are in agreement with (Stefan et al., A\&B 2013 and Malinda et al., 2019) who reported that seed inoculation with plant growth promoting rhizobacteria $\left(\mathrm{N}_{2}\right.$.fixter bacteria) for Phaseolus plants in combination with some organic and inorganic substance have a great potential to increase leaves content of chl. A, chl. B, chl. T, and carot. (mg per $\mathrm{g}$ ) for Phaseolus plants. 
Table 5. Photosynthesis pigment ( $\mathrm{chl}_{1}, \mathrm{chl}_{2}$, chl. (total) and carotene) contents of leaves as affected by application the two inoculation methods under different fertilization treatment (At 60 DAP).

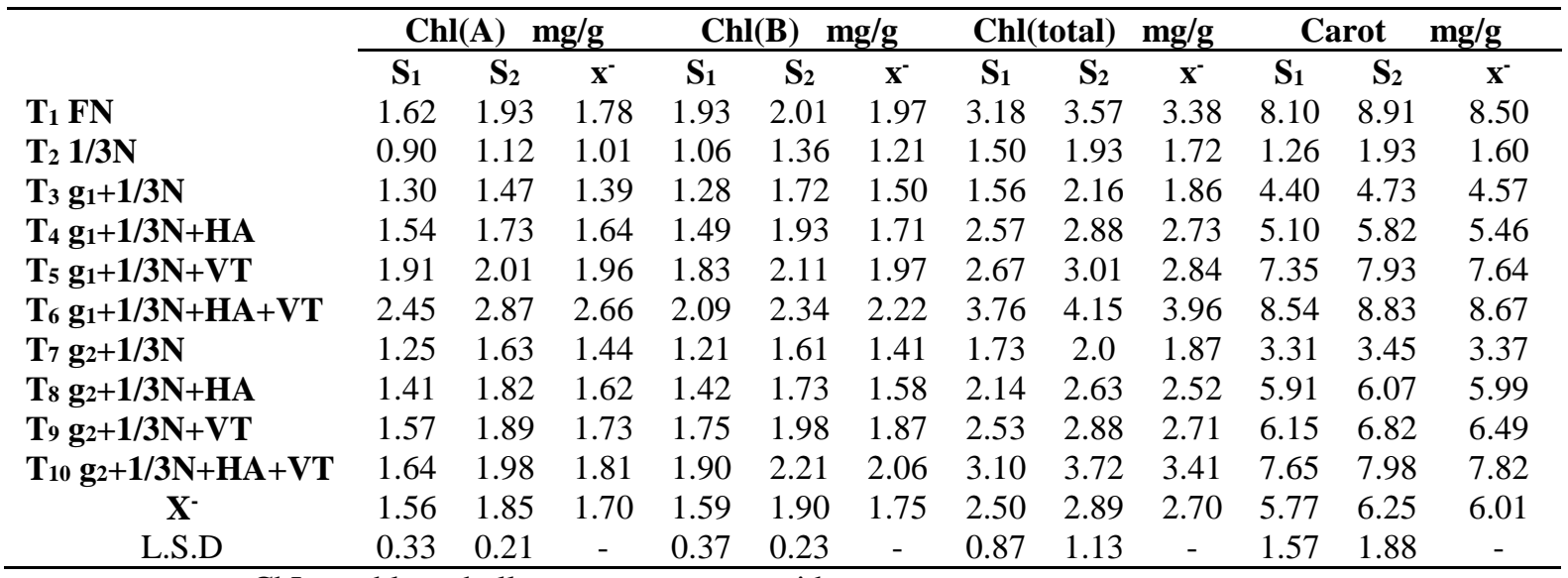

ChL - chlorophyll - carot - carotenoids.

Data given in Table (6) indicated that significant difference were found among the various treatment for $\mathrm{N}, \mathrm{P}, \mathrm{K}(\%)$ and plant N. Content (mg per plant).

Application of either humic acid and Vermicompost tea as such or in combination with inoculated Bean plants $+1 / 3 \mathrm{~N}$ did support $\mathrm{N}, \mathrm{P}$ and $\mathrm{K}$ uptake (\%) and the higher values were found at $\mathrm{T}_{7}$ and $\mathrm{T}_{10}$ and scored 3.05,1.45 and 2.29 and 2.98,1.48 and
2.17 for $\mathrm{N}, \mathrm{P}$ and $\mathrm{K}$ at $\mathrm{T} 7$ and $\mathrm{T}_{10}$ respectively. The higher plant $\mathrm{N}$. content was found at the treatments which received full dose of $\mathrm{N}$. fertilizer $\left(\mathrm{T}_{1}\right) 51.98$ followed by $\left(\mathrm{T}_{6}\right) 44.99$ and $\left(\mathrm{T}_{10}\right) 42.92$ these results are in harmony with obtained by (Aracon 2005; Mahana et al., 2015; Conallas and Olivares 2016 and Malinda et al., 2019) who reported that preferably.

Table 6. $\mathrm{N}$ "P and $\mathrm{K} \%$ as well as plant $\mathrm{N}$ content of Bean plants as affected by application the two different inoculation methods under virous fertilization treatments (at 60 DAP).

\begin{tabular}{|c|c|c|c|c|c|c|c|c|c|c|c|c|}
\hline & \multicolumn{3}{|c|}{$(\mathbf{N \%})$} & \multicolumn{3}{|c|}{ Plant $N$ content } & \multicolumn{3}{|c|}{$(\mathbf{P \%})$} & \multicolumn{3}{|c|}{$(\mathrm{K} \%)$} \\
\hline & $\mathbf{S}_{1}$ & $\mathbf{S}_{2}$ & $\mathbf{x}^{-}$ & $\mathbf{S}_{1}$ & $\mathbf{S}_{2}$ & $\mathbf{x}^{-}$ & $\mathbf{S}_{1}$ & $\mathbf{S}_{\mathbf{2}}$ & $\mathbf{x}^{-}$ & $\mathbf{S}_{1}$ & $\mathbf{S}_{2}$ & $\mathbf{x}^{-}$ \\
\hline $\mathrm{T}_{1} \mathrm{FN}$ & 3.20 & 3.32 & 3.21 & 50.88 & 52.49 & 51.85 & 1.56 & 1.61 & 1.58 & 2.60 & 2.75 & 2.68 \\
\hline$T_{2} \mathbf{1} / 3 N$ & 2.66 & 2.70 & 2.68 & 32.19 & 33.48 & 32.84 & 0.96 & 0.98 & 0.97 & 1.27 & 1.35 & 1.31 \\
\hline$T_{3} g_{1+1 / 3 N}$ & 2.80 & 2.83 & 2.82 & 36.68 & 37.51 & 37.10 & 1.04 & 1.11 & 1.08 & 1.55 & 1.63 & 1.59 \\
\hline$T_{4} g_{1+1 / 3 N+H A}$ & 2.86 & 2.89 & 2.88 & 39.47 & 40.17 & 39.82 & 1.17 & 1.25 & 1.21 & 1.65 & 1.70 & 1.68 \\
\hline$T_{5} g_{1}+1 / 3 N+V T$ & 2.94 & 2.98 & 2.96 & 42.04 & 42.91 & 42.48 & 1.30 & 1.43 & 1.37 & 1.75 & 1.83 & 1.79 \\
\hline $\begin{array}{l}T_{6} \\
g_{1}+1 / 3 N+H A+V T\end{array}$ & 2.99 & 3.11 & 3.05 & 43.95 & 46.03 & 44.99 & 1.41 & 1.48 & 1.45 & 2.20 & 2.37 & 2.29 \\
\hline $\mathrm{T}_{7} \mathrm{~g}_{2}+\mathbf{1} / \mathbf{3 N}$ & 2.69 & 2.73 & 2.71 & 34.70 & 35.76 & 35.23 & 1.10 & 1.24 & 1.17 & 1.37 & 1.48 & 1.43 \\
\hline $\mathrm{T}_{8} \mathrm{~g}_{2+1 / 3 \mathrm{~N}+\mathrm{HA}}$ & 2.75 & 2.79 & 2.77 & 36.58 & 37.67 & 37.13 & 1.28 & 1.37 & 1.33 & 1.56 & 1.63 & 1.60 \\
\hline$T_{9} g_{2}+1 / 3 N+V T$ & 2.81 & 2.84 & 2.83 & 39.06 & 40.33 & 39.70 & 1.34 & 1.47 & 1.41 & 1.67 & 1.72 & 1.70 \\
\hline $\begin{array}{l}T_{10} \\
g_{2}+1 / 3 N+H A+V T\end{array}$ & 2.95 & 3.01 & 2.98 & 42.19 & 43.65 & 42.92 & 1.45 & 1.50 & 1.48 & 2.10 & 2.23 & 2.17 \\
\hline $\mathbf{X}^{-}$ & 2.87 & 2.91 & 2.89 & 39.81 & 41.00 & 40.41 & 1.26 & 1.34 & 1.30 & 1.77 & 1.87 & 1.82 \\
\hline L.S.D & 0.09 & 0.12 & - & 8.56 & 9.12 & - & 0.04 & 0.06 & - & 0.57 & 0.63 & - \\
\hline
\end{tabular}

to use organic fertilizer or some organic promoting substance with inoculated been plant with lower (stater) dose of nitrogen $(1 / 3 \mathrm{~N})$ to obtain higher response to $\mathrm{N}, \mathrm{P}$ and $\mathrm{K}$ uptake and increased plant $\mathrm{N}$ content. 
Table 7. Number of pods per plant, seed yield g per plant and seed yield g per pot of bean plants as affected by application the two different inoculation methods under virous fertilization treatments (at 120 DAP).

\begin{tabular}{|c|c|c|c|c|c|c|c|c|c|}
\hline & \multicolumn{3}{|c|}{ Number of pod per plant } & \multicolumn{3}{|c|}{$\begin{array}{l}\text { Yield per plant } \\
\text { (gm per plant) }\end{array}$} & \multicolumn{3}{|c|}{$\begin{array}{c}\text { yield per pot } \\
\text { (g per pot) }\end{array}$} \\
\hline & $\mathbf{S}_{\boldsymbol{1}}$ & $\mathbf{S}_{2}$ & $\mathbf{x}^{-}$ & $\mathbf{S}_{1}$ & $\mathbf{S}_{2}$ & $\mathbf{X}^{-}$ & $\mathbf{S}_{1}$ & $\mathbf{S}_{2}$ & $\mathrm{X}^{-}$ \\
\hline $\mathbf{T}_{1} \mathbf{F N}$ & 11 & 14 & 13 & 37.60 & 39.20 & 38.4 & 150.40 & 156.8 & 153.6 \\
\hline $\mathbf{T}_{2} \mathbf{1 / 3 N}$ & 3 & 5 & 4 & 11.50 & 13.50 & 12.5 & 46.00 & 54.0 & 50.0 \\
\hline $\mathrm{T}_{3} \mathrm{~g}_{1}+1 / 3 \mathrm{~N}$ & 4 & 6 & 5 & 14.70 & 14.70 & 14.7 & 58.8 & 58.8 & 58.8 \\
\hline $\mathrm{T}_{4} \mathrm{~g}_{1}+1 / 3 \mathrm{~N}+\mathrm{HA}$ & 6 & 8 & 7 & 16.10 & 17.80 & 16.9 & 64.4 & 71.2 & 6708 \\
\hline $\mathrm{T}_{5} \mathrm{~g}_{1}+\mathbf{1} / \mathbf{3 N}+\mathrm{VT}$ & 7 & 10 & 9 & 22.70 & 26.11 & 24.40 & 90.8 & 104.4 & 97.6 \\
\hline $\mathrm{T}_{6} \mathrm{~g}_{1}+1 / 3 \mathrm{~N}+\mathrm{HA}+\mathrm{VT}$ & 10 & 11 & 11 & 23.50 & 29.70 & 26.6 & 94.0 & 118.8 & 106.4 \\
\hline$T_{7} g_{2}+1 / 3 N$ & 6 & 8 & 7 & 18.30 & 20.50 & 19.4 & 73.2 & 82.0 & 77.6 \\
\hline $\mathrm{T}_{8} \mathrm{~g}_{2}+1 / 3 \mathrm{~N}+\mathrm{HA}$ & 9 & 10 & 10 & 24.10 & 28.70 & 26.4 & 96.4 & 114.8 & 105.6 \\
\hline $\mathrm{T}_{9} \mathrm{~g}_{2}+1 / 3 \mathrm{~N}+\mathrm{VT}$ & 10 & 11 & 11 & 29.70 & 31.80 & 30.8 & 118.8 & 127.2 & 123.0 \\
\hline $\mathrm{T}_{10} \mathrm{~g}_{2}+1 / 3 \mathrm{~N}+\mathrm{HA}+\mathrm{VT}$ & 11 & 13 & 12 & 35.90 & 36.20 & 36.1 & 143.6 & 144.8 & 144.2 \\
\hline L.S.D & 0.98 & 1.13 & - & 2.74 & 2.81 & - & 831 & 13.67 & - \\
\hline
\end{tabular}

Data presented in table (7) indicated that application of both humic acid and /or vermicompost tea with inoculated Phaseolus plant with the two inoculation methods $\left(\mathrm{g}_{1}\right.$ and $\left.\mathrm{g}_{2}\right)$ gave higher values for both pod number per plant and seed yield $g$ per plant and these values ranged from 6 to 12 and from 16.9 to 36.1 for pod number and seed yield per plants, respectively. The lowest for both pod number per plant and seed yield gm per plants were found at the treatment which received $1 / 3 \mathrm{~N}$-mireal fertilizer as such or in combination with bacterial inoculation as compared to other treatments among the two seasons.

Results of seed yield gm per pot as shown in table (7) revealed that the highest values were found at the treatment which received the full dose of mineral fertilizer and these values were 150.4 and 156.8 for season one and season two, respectively. But there was no significant differences were found at the treatments which received rhizobial inoculation + $1 / 3 \mathrm{~N}$ dose + both humic acid and vermicompost tea and these values were 143.6 and 144.8 for season one and season two, respectively. These results are in agreement with those obtained by Abo Tabeb et al 3003, Mohana et al 2015, Javed et al 2017, Rurongwa et al 2018 and Malinda et al 2019 who reported that application of rhizobial inoculation in combination of same organic fertilizer treatments $i$,e addition of organic promoting subs tans (Humic acid and compost tea or vermicompost tea ) or compost and or vermicompost led to give an activation effect on vegetative growth, yield and yield components of Phaseolus plants under different soil conditions.

\section{Conclusion}

The results demonstrate that both inoculation methods of Phaseolus plants in combination with organic promoting substance can improve nodulation vegetative, growth, shoot $\mathrm{N}$ content photosynthesis pigment content and N, P and $\mathrm{K}$ uptake (as\%) and seed yield of Phaseolus plants under low amount of mineral $\mathrm{N}$. fertilizer. These are meaning reducing both agriculture coast and environmental pollution.

\section{Reference}

Abo Taleb H.H; El-Khatib, Mona A. M. Soliman and A.A. Abo El-soud (2003). Complementation of diazotroph inoculation to ameliorate Phaseolus production in draping at el environments. J. Soil and Agric. Eng, Mansura , 28(4): 2515 - 2524.

Aracon, N. Q; J. D. Metzger and Edwards, C. A. (2005). Effect of Vermicompost on plant growth. ISWVT, Los Banos Philippines Ines Nov, 16-18

Canallas, L. P. and F. L. Olivares (2016). physiological response to humic substance as plant growth promoter. Chem Bio L. Techno. Agric. 1-3.

Edwards, C. A.; J. Dominiquer and Arancon N. Q. (2004). The influence of Vermicompost on plant growth and pest incidence. pp 396-420.

El-Maas; Enshrah, I. M. and Ismail. Fatma, S. H. (2016). Impact of bio fertilizer, Humic acid and compost tea application on soil properties and Egyptian clover productivity under slaime soil condition. J. Soil and Agric. Eng, Mansura

Elmehrat, H. G; A. M. R. A. Abdelaziz and Mohamed M. A. A. (2018). Effec of potassium silicate, Vermicompost tea and Bio fertilizer on ARRAis Grape beers quality at harverte and during storage. Menoufia J. Plant prod vol $3: 251.26$

Jackson, M. L. (1973). Soil chemical analysis perenticet Hall, my. Englewood Cliffs,

Javed, M. K. S. Khan, M. Akmal and Quershi, K. M. (2017). Vermicompost application improves yield and quality of table grapes varkings ruby (vitic vinitera). International J. Of Biosci, 10 (1):152-164. 
Khalal, H. M; Lialia, M. K. Ali and Eeassa A. A. M. (2011). Impact of applied humic and fulvic acids on the soil physis -chemical properties and cucumber productivety under probucted cultivation condition. J. Sci and Agric Eng. Mansoura University, Vol 2 (2):11-22.

Liu, Y. L.; Wu, J. A. Baddeley and Watson, C. A. (2011). Models of biological nitrogen fixation of legumes. A review. Agron sustain 31:155-172.

Malinda, S. T.; chapagain, T.; Ghimire, B.; Pudasaini, R.; tamang B.; Gurumg K.; Choi, K.; Rar, L.; Magar, S. B. K.; Gaire, S. and Manish, N. R. (2019). Evaluating the Effectiveness of Rhizobacterium inowlant and micronutrients as technologies for $\mathrm{Ne}$ palese common Phaseolus small holder farmers in the Real. Word context of highly variable Hillside environment and mdigenous farming practices. Agriculture, 2019,9,2 W. W. W. mdpi. Com. /Joumal /agriculture.

Mohana, A. A.; Suleiman M. M. and khedr, W. S. (2015). Effect of Humic acid and notes of nitrogen fertilizer on yield and yield components of corn (zea mays L) Jord. J. Agric sci, 11 (1):229-241.

Musandu, A. A. O. and O. U. Joshia (2001). Response of common Phaseolus to Rhizobium inoculation and fertilizer. J. Food Techol Afr, 6:121-125.

Pane, C. A. M.; Palese, R.; Spaccini, A.; Piccoio, G.; Celanopand zaccardelli, M. (2016). Enhancing sustainability of a processing tomato cultivation system by using bio active compost tea. Scientia culture, 202:117-124.

Pase, A. L; Miller, R. H. and Keeney D. R. (1982). Methods of soil Analysis II chemical and microbiological properties. Soil Sci Am. Madison Wisconsin, USA.
Rurangwa, E.; B. Vanlauvve and Giller K. E. (2018). Benefits of inoculation, $p$ fertilizer and manure on yield of common Phaseolus and soy Phaseolus also increase yield of subsequent maize. Agric. Ecosyst. Environment, 216:219-229.

Schaebitz, M.; Lopez, M. D.; Serri, H.; Martinez, O. and zagal, E. (2106). Combined application of microbial consortium and humic acid substance to improve the growth performance of blueberry seedlings. J. Soil sci. Plant Nutr. 16:1010-1023.

Shakir, I. S. H. and Mikhaill, W. Z. A. (2019). Soil zoology in sustainable development opment in the 21 St century, El Cairo. Egypt.

Srinivaon, M, Peterson. D. J, and F. B. Holl (1997). Modulation of phaseolus vulgaris by Rhizobium etliis enhancement by presence of Bacillus. Can. J. Microbiol 43:1-8

Steel, R. G. D; J. H. Torri and D. A. Dickey (1997). Princi ples and procedures of statistics, Abiometrical Appropriate ach, 3rd. Megraw. Hill. New York 666p.

Stefan, M. N.; Munteanu, U.; stoleru, M. Mihasan and L. A. Hritcu (2013 ${ }^{\text {a) }}$. Seed inoculation with plant growth promoting rhizobacteria enhances photosynthesis and yield of runner Phaseolus (phaseolus coccineus L) Scientia Hortic, 151 (0): 22-29.

Stefan, M.; N. Munteanu, U. Stoleru and Mihasan, M. $\left(\mathbf{2 0 1 3}^{\mathrm{b}}\right)$. Effect of inoculation with plant growth promoting on photosynthesis, antioxidant status and yield of runner Phaseolus . Romanian Biotech. Let, vol. 18(2): 8132-8143.

Zehra, E. (2019). integrated use of Humic acid and plant growth promoting rhizobacteria to ensure higher potata productivity in sustainable agriculture. W. W. W mdpi. Com. J. Sustainability. 11, 3417, dor 10.3390 sic 11123417 . 
تاثير إستخدام شاي الفيرمكومبوست والهيومك علي حاله التعقيد والنمو الخضري والمحصول لنباتات الفاصوليا

منى حسين عبدالفتاح حسين 1 ، هبة سعيد الاسوقى 2

قسم الميكروبيولجى - معهُ بحوث الاراضى والمياه والبيئه

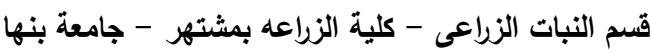

أجريث تجربتان اصص بصوبة معهد بحوث الاراضى والمياة بمركز البحوث الزراعية الجيزة مصر خلال موسمى النمو 2020/2019

لدراسة تأثير الاضافة للقاح الريزوبيم بسلاتين مختلفتين ، الهيومك وشاى الكمبوست كل منهم منفردا والتفاعل فيما بينهم على النمو الخضرى وتكوين

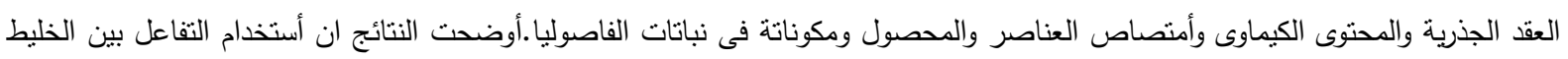

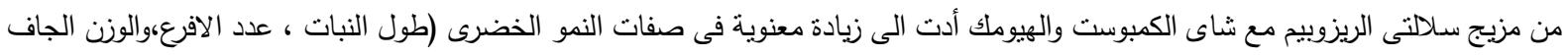

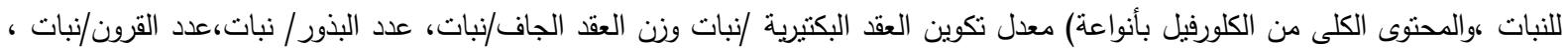
ومحصول النبات وخلال موسمى النمو 2020/2019 ـ فى نفس السياق المعاملات الاخرى ادت الى زيادة فى كل الصفات المدروسة مقارنة بالنبانات الغير معاملة ولكن لم تصل الى مستوى المعاملة السابقة خلال موسمى النمو . 